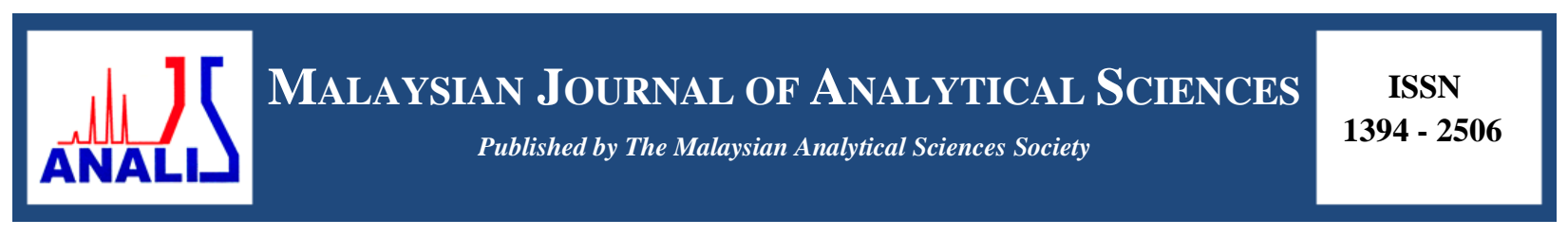

\title{
METHANOL PERMEABILITY AND PROPERTIES OF POLYMER ELECTROLYTE MEMBRANE BASED ON GRAPHENE OXIDE- SULFONATED (POLYETHER ETHER) KETONE
}

\author{
(Kebolehtelapan Metanol dan Sifat-Sifat Membran Polimer Elektrolit Berasaskan Grafin \\ Oksida-Polieter Eter Keton Tersulfon)
}

\author{
Nuor Sariyan Suhaimin ${ }^{1}$, Madzlan Aziz ${ }^{1,2 *}$, Juhana Jaafar ${ }^{2}$ \\ ${ }^{1}$ Chemistry Department, Faculty of Science \\ ${ }^{2}$ Advanced Membrane Technology Research Centre \\ Universiti Teknologi Malaysia, 81310 Skudai, Johor, Malaysia \\ *Corresponding author: madzlan@utm.my
}

Received: 26 August 2016; Accepted: 8 January 2017

\begin{abstract}
Graphene oxide sulfonated polyether ether ketone (GO-SPEEK) is a promising proton exchange membrane (PEM) to replace the commercial PEM in Direct Methanol Fuel Cell (DMFC) application. The GO films were prepared from natural graphite flakes by the modified Hummer's Method. The structure and physicochemical characterization techniques were applied to impart insight into the specific structure, element composition as well as the functional groups by using Attenuated Total Reflection infrared spectroscopy (ATR), X-Ray diffraction (XRD), and Raman Spectroscopy. The incorporation of graphene oxide in SPEEK not only improved membrane behaviors of PEM in terms of ion exchange capacity $\left(1.231 \mathrm{mequiv}^{-1} \mathrm{~g}^{-1}\right)$, water uptake $(53.45 \%)$ and proton conductivity (0.0537), but also positively blocking of methanol molecules passing through membrane, thus making them appealing as proton exchange membranes (PEMs).
\end{abstract}

Keywords: graphene oxide, sulfonated polyether ether ketone, proton exchange membrane, X-ray diffraction

\begin{abstract}
Abstrak
Grafin oksida sulfona polieter eter keton (GO-SPEEK) merupakan proton pertukaran membran (PEM) yang menjanjikan pengantian PEM komersial dalam aplikasi sel bahan api metanol langsung (DMFC). Filem GO dihasilkan daripada grafit semulajadi menggunakan kaedah Hummer diubahsuai. Teknik - teknik pencirian struktur fizikal dan kimia telah digunakan untuk mendapatkan maklumat tentang struktur spesifik, komposisi elemen dan juga kumpulan berfungsi dengan menggunakan ATR spektroskopi inframerah, pembelauan sinar-X (XRD), dan spektroskopi Raman. Penambahan grafin oksida kedalam sulfona poli (eter eter keton) bukan sahaja meningkatkan prestasi PEM dari aspek kapasiti pertukaran ion (1.231 mequiv. $\left.\mathrm{g}^{-1}\right)$, pengambilan air (53.45\%) dan kekonduksian proton (0.0537), tetapi juga mampu untuk menahan molekul metanol dari merentasi membran, sekaligus menjadikannya sangat sesuai sebagai PEM.
\end{abstract}

Kata kunci: grafin oksida, polieter eter keton tersulfon, proton pertukaran membran, pembelauan sinar-X

\section{Introduction}

Fuel cells are electrochemical devices that manage to directly convert chemical energy into electrical energy. Thus, it offers a promising alternative to conventional fossil fuel systems, due to their high efficiency, environmental 


\section{Nuor Sariyan et al: METHANOL PERMEABILITY AND PROPERTIES OF POLYMER ELECTROLYTE MEMBRANE BASED ON GRAPHENE OXIDE- SULFONATED (POLYETHER ETHER) KETONE}

friendly and flexible application. Among them, proton exchange membrane fuel cell (PEMFC) has been gaining much attention due to its low system complexity, with high power density.

The proton exchange membrane (PEM), a thin membrane plays a crucial role in the performance of PEMFC as it is the heart of the PEMFC system enables fuel cells to conduct its electron by attracting the protons, and enabling them to diffuse through the layer, while maintaining their proton state. One of the most common and commercially available PEMs is the Dupont's Nafion ${ }^{\circledR}$ due to their high proton conductivity and chemical stability. However, the performance efficiency and application has been greatly hindered by several challenges such as high cost, methanol crossover and loss of conductivity above $80^{\circ} \mathrm{C}$ in DMFC [1].

To overcome these issues, many studies have been conducted to develop affordable PEM with low methanol permeability for DMFC applications [2 - 4]. Sulfonated poly (ether ether ketone)(SPEEK), the most influential sulfonated aromatic polymer, is widely considered as a promising polymer electrolyte for proton exchange membrane fuel cells (PEMFC) as it offers adequate proton conductivity with low cost of production [5].

\section{Materials and Methods}

The materials used in the experiments were included of commercial graphite powder (60-85\%) supplied by Superior Graphite Co. while hydrochloric acid $(\mathrm{HCl}, 37 \%)$, sodium hydroxide $(\mathrm{NaOH})$, sodium nitrate $\left(\mathrm{NaNO}_{3}\right)$ and sulfuric acid $\left(\mathrm{H}_{2} \mathrm{SO}_{4}, 95-97 \%\right)$ were from Merck. Potassium permanganate $\left(\mathrm{KMnO}_{4}, 99 \%\right)$ was purchased from Bendosen. Hydrogen peroxide $\left(\mathrm{H}_{2} \mathrm{O}_{2}, 35 \%\right)$. All materials were used as received. Distilled water was used throughout this study.

\section{Preparation of graphene oxide films}

In order to prepare graphene oxide (GO), natural graphite powders and $\mathrm{NaNO}_{3}$ are added slowly into the concentrated $\mathrm{H}_{2} \mathrm{SO}_{4}$ in ice bath with constant stirring for $45 \mathrm{~min}$. Then, $\mathrm{KMnO}_{4}(6 \mathrm{~g})$ is added slowly to the solution and ensured the mixture temperature not exceeding $5{ }^{\circ} \mathrm{C}$. The mixture then kept stirred for 1 hour before removing the ice bath. At intermediate temperature stage $\left(35-37^{\circ} \mathrm{C}\right)$ the mixture was stirred for 1 hour until it became pasty brownish. The reaction was continued with addition of distilled water $(115 \mathrm{~mL})$ resulting in sudden increases of temperature which was maintained at $90{ }^{\circ} \mathrm{C}$ for $15 \mathrm{~min}$. Finally, the oxidation reaction was terminated by the addition of distilled water $(350 \mathrm{~mL})$ and $\mathrm{H}_{2} \mathrm{O}_{2}(30 \%, 10 \mathrm{~mL})$. The mixture then left overnight with agitation to ensure its homogeneity followed by washing with $\mathrm{HCl}$ for several times. After that, the yield will be washed with distilled water several times and sonicated for $30 \mathrm{~min}$ in order to obtain the GO solution. The dry form of GO was obtained after drying for 24 hours in the oven [6,7].

\section{Preparation of SPEEK and GO-SPEEK}

For preparation of proton exchange membrane (PEM), $10 \mathrm{wt} . \%$ of SPEEK solution was prepared by dissolving SPEEK in DMSO. An amount $0.1 \mathrm{~g}$ of GO were added into DMSO and stirred for 3 hours to produce homogeneous solution. This solution then added into SPEEK solution, and the mixture was vigorously stirred for 24 hours at room temperature in order to produce homogeneous solution. The mixture then heated to $100{ }^{\circ} \mathrm{C}$ to evaporate the DMSO solvent. This preparation method was known as solution intercalation method. The solution then was cast on a glass plate with casting knife to form a solution film. The resultant film then dried in oven for 24 hours at $70{ }^{\circ} \mathrm{C}$. The membrane was further dried for 6 hours at $100{ }^{\circ} \mathrm{C}$ to completely remove residual solvent. Finally, the membrane was treated with $1 \mathrm{M}$ sulfuric acid solution for 24 hours at room temperature and subsequently rinsed with water several times in order to remove the remaining acid [8].

\section{Characterization of GO and hybrid nanomaterial}

In order to characterize GO and PEM, the samples were examined by Perkin Elmer Spectrum One ATR in the mid IR region. The morphology of samples was determined by Field-Emission Scanning Electron Microscope (FESEM) model Hitachi SU8020. All X-ray diffraction (XRD) spectra of GO and PEM were scanned by Bruker Advance D8 Siemens 500 diffractometer, using $\mathrm{Cu} \mathrm{K} \alpha$ radiation $(\lambda=0.15418 \mathrm{~nm}, 40 \mathrm{kV}, 40 \mathrm{~mA})$. The scanning rate is $1 \mathrm{~s}$ with interval of $0.05^{\circ}, 2 \theta$ range of $20^{\circ}-80^{\circ}$ in the ambient temperature. Raman spectra were recorded from 200 to 2000 $\mathrm{cm}^{-1}$ on a Reninshaw Via-Reflex Concoal Raman Microprobe of England using a $532 \mathrm{~nm}$ excitation. 
Liquid uptake measurement is a technique to study the swelling behavior of SPEEK and GO-SPEEK membrane. The membranes will be dried in oven at $60{ }^{\circ} \mathrm{C}$ for 48 hours. The films will be initially weighted before soaking in deionized water for overnight at room temperature, and then will be blotted dry with adsorbent paper to remove any surface moisture. It then will be reweighted. The water uptake will be calculated as follows (equation 1):

$$
\text { Water Uptake }=\left(\mathrm{W}_{\mathrm{w}}-\mathrm{W}_{\mathrm{d}}\right) / \mathrm{W}_{\mathrm{d}} \times 100
$$

where $\mathrm{W}_{\mathrm{w}}$ and $\mathrm{W}_{\mathrm{d}}$ are the weights of the wet membrane and the dry membrane, respectively.

The proton conductivity was measured by impedance spectroscopy over a frequency range of $1 \mathrm{~Hz}$ to $107 \mathrm{~Hz}$ with $50 \mathrm{mV}$ to $500 \mathrm{mV}$ oscillating voltage, using solatron 1260 gain phase analyzer. The ion exchange capacity (IEC) of the membranes was measured with the titration technique. GO-SPEEK and Nafion were soaked in a large volume of $0.1 \mathrm{~mol} \mathrm{~L}^{-1} \mathrm{HCl}$ solution, washed with distilled water to remove excess $\mathrm{HCl}$ and then immersed in $1 \mathrm{M}$ sodium chloride $(\mathrm{NaCl})$ aqueous solution to release protons from the membrane. The released $\mathrm{H}^{+}$was back titrated with a $0.01 \mathrm{M}$ sodium hydroxide $(\mathrm{NaOH})$ aqueous solution using phenolphthalein as an indicator. The IEC value (in meq. $\mathrm{g}^{-1}$ ), which is defined as milli equivalents (meq.) of sulfonic groups per gram of dried sample is obtained from the following equation 2 :

$$
\mathrm{IEC}=\mathrm{V}_{\mathrm{NaOH}} \times \mathrm{C}_{\mathrm{NaOH}} / \mathrm{W}_{\mathrm{dry}}
$$

where $\mathrm{V}_{\mathrm{NaOH}}$ is the volume of $\mathrm{NaOH}$ consumed, $\mathrm{C}_{\mathrm{NaOH}}$ is the concentration of $\mathrm{NaOH}$ and $\mathrm{W}_{\text {dry }}$ is the weight of the dry membrane (g) [9].

The methanol permeability of membrane was measured using permeation cell composed of two reservoirs, each with a capacity of $50 \mathrm{ml}$. Before the test, the membranes were prehydrated for at least 24 hours. Each reservoir was separated by membrane. One reservoir was filled with a $1 \mathrm{M}$ methanol solution, and deionized water was placed in the other reservoir. Both compartments were stirred continuously with a magnetic stirrer during the permeability experiment. The methanol permeability was found using this equation 3 :

$$
C_{B}(t)=A / V_{B} \times(D K / L) C_{A}\left(t-t_{0}\right)
$$

where $C_{A}$ and $C_{B}$ are the concentrations of methanol in the donor and receptor reservoirs. A and $L$ are the diffusion area and thickness of the membrane, respectively. The product of $\mathrm{D}$ and $\mathrm{K}$ is the methanol permeability $\left(\mathrm{cm}^{2} \mathrm{~s}^{-1}\right)$.

\section{Attenuated total reflection infrared spectrometer}

\section{Results and Discussion}

The availability of functional groups in GO and the chemical interactions between the functional groups of GO and SPEEK were examined by ATR spectroscopy. Figure 1 depicted the spectra of GO and GO-SPEEK. The spectrum of GO illustrates a strong and broad absorption in the range of $3700-2000 \mathrm{~cm}^{-1}$ can be assigned to the stretching vibrations of structural $\mathrm{OH}$ groups and physisorbed water molecules. The band at $1716.8 \mathrm{~cm}^{-1}$ can be ascribed to the $\mathrm{C}=\mathrm{O}$ stretching vibration of $\mathrm{COOH}$ groups, and the absorptions arising from the $\mathrm{O}-\mathrm{H}$ bending vibration, epoxide groups and skeletal ring vibrations are observed at $1619.08 \mathrm{~cm}^{-1}$. The peaks at $1389.89 \mathrm{~cm}^{-1}$ represent the O-H deformation vibration of $\mathrm{COOH}$ groups and can be used to evaluate the amount of $\mathrm{COOH}$ groups. The appearance of absorption at $1233.6 \mathrm{~cm}^{-1}$ is related to phenolic groups. The $1044.72 \mathrm{~cm}^{-1}$ is assigned to C-O-C stretching vibrations which confirm the presence of epoxide group in GO layers. For GO-SPEEK spectra, the presence of sulfonic acid group in SPEEK was confirmed by the strong characteristic peaks at 1219.72, 1081.93 and 1024.82 $\mathrm{cm}^{-1}$, were assigned to the symmetric and asymmetric $\mathrm{O}=\mathrm{S}=\mathrm{O}$ stretching vibrations, as their intensities with respect to the backbone carbonyl $(\mathrm{C}=\mathrm{O})$ band at $1641.32 \mathrm{~cm}^{-1}$. The broad peak appearing at $3412 \mathrm{~cm}^{-1}$ assigned to $\mathrm{O}-\mathrm{H}$ vibration double confirmed the presence of sulfonic acid groups in SPEEK samples, which interacting with molecular water [10]. 


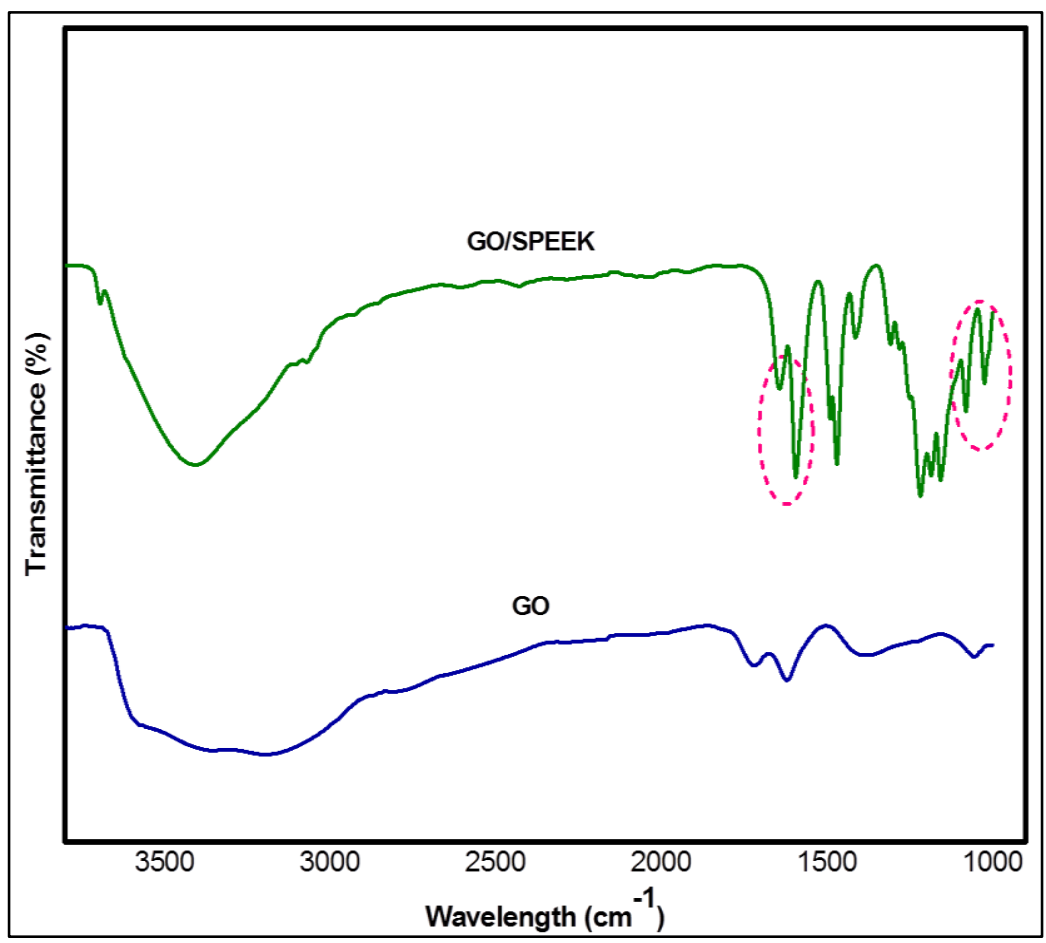

Figure 1. ATR spectra of GO and GO-SPEEK

\section{Raman spectroscopy}

Typical Raman spectra of pristine graphite, GO and GO-SPEEK obtained at an excitation wavelength of $532 \mathrm{~nm}$ are shown in Figure 2. Graphite shows a single sharp peak G band at $\sim 1581 \mathrm{~cm}^{-1}$, which corresponds to the vibration of $\mathrm{sp}^{2}$ network, and low intensity of $\mathrm{D}$ band indicates defects existed in the graphite edges at $1354 \mathrm{~cm}^{-1}$. In Raman spectra, the oxidation of graphite can be manifested by the changes in the relative intensity of two main D and G peaks. In comparison with graphite, GO exhibits a broader and blue-shifted $\mathrm{G}$ band at around $1580 \mathrm{~cm}^{-1}$ with an intense D band at $1350 \mathrm{~cm}^{-1}$ which is consistent with literature reported values [11-14]. During oxidation, the intensity of the $\mathrm{D}$ bands increase significantly, suggesting increased disorder and symmetry breaking in the graphitic layers due to attachment of hydroxyl and epoxide groups on the carbon basal plane. After incorporation GO into SPEEK, the $\mathrm{D}$ and $\mathrm{G}$ band for $\mathrm{GO}$ can't be observed as the spectra present at 1152.32 assigned to $\mathrm{O}=\mathrm{S}=\mathrm{O}$ vibration for $\mathrm{SO}_{3} \mathrm{H}$ group.

\section{Field emission scanning electron microscopy (FESEM)}

Field emission scanning electron microscopy (FESEM) images of GO, SPEEK and GO-SPEEK are shown in Figure 3. It can be observed (Figure 3a) that after oxidation, the GO shows an agglomeration of the exfoliated flakes. Moreover, there is some wrinkles and folding on the surfaces and edges indicating that the graphitic domain was decorated with oxygen-containing functional groups. Besides, the morphological features of the membranes show the microscale images of the cross-sectional area of SPEEK and GO-SPEEK (Figure 3b and 3c) with sponge-like structures. The various sizes of GO particles are visible in the GO-SPEEK membrane. These fillers are uniformly distributed throughout the matrix due to the interfacial interaction, which is attributed between the sulfonic group of SPEEK and the oxygenated group of GO through hydrogen bonding. 


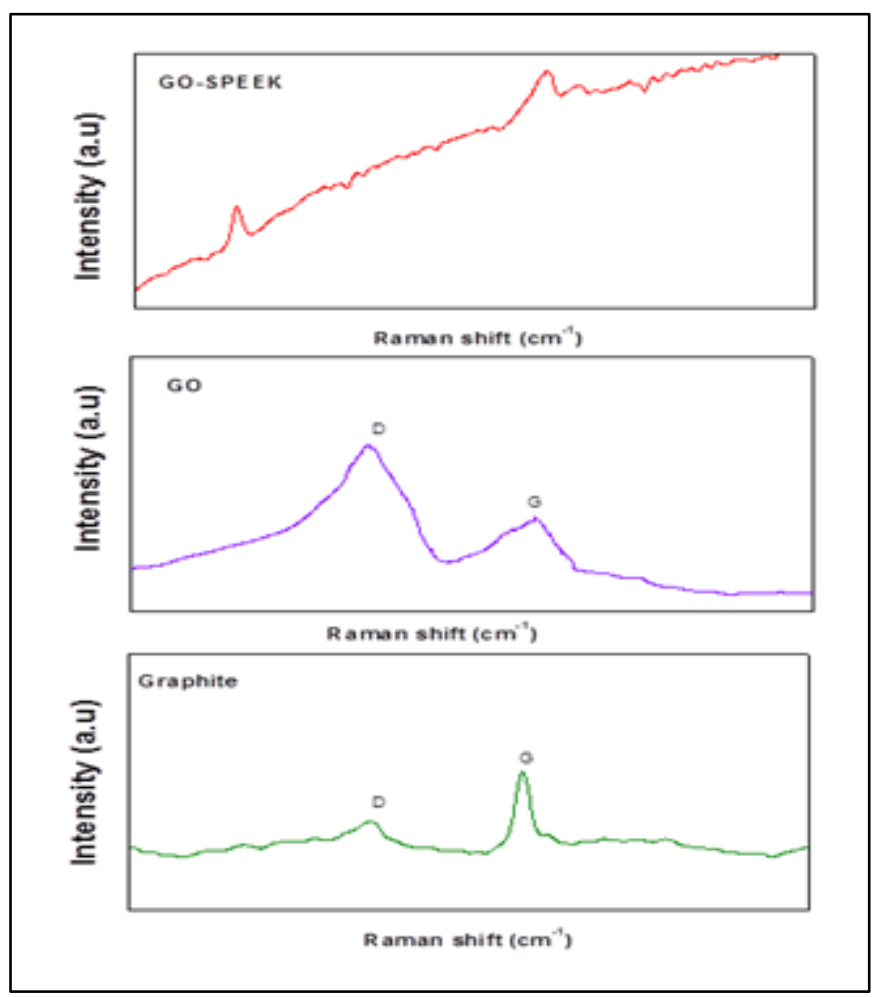

Figure 2. Raman spectra for graphite, GO and GO-SPEEK
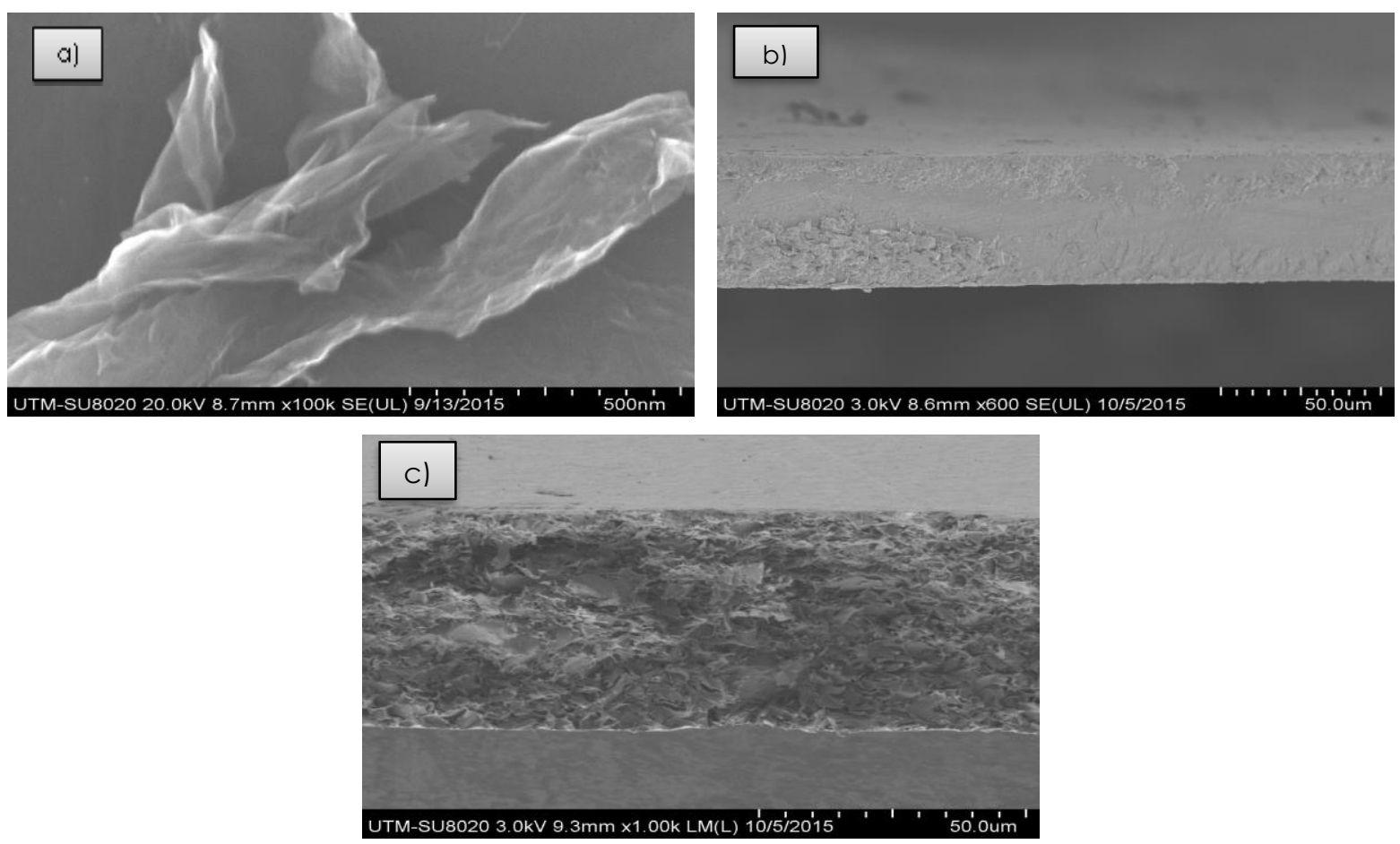

Figure 3. FESEM image of (a) GO, (b) SPEEK, and (c) GO-SPEEK 


\section{Nuor Sariyan et al: METHANOL PERMEABILITY AND PROPERTIES OF POLYMER ELECTROLYTE MEMBRANE BASED ON GRAPHENE OXIDE- SULFONATED (POLYETHER ETHER) KETONE}

\section{X-ray diffraction}

Figure 4 illustrates XRD of graphite, GO, SPEEK and GO-SPEEK. This method can be used to confirm exfoliation process occurred in the pristine graphite during the oxidation process. The pattern of the raw graphite shows a very strong (002) peak at $2 \theta=26.35^{\circ}$ for a typical graphitic structure with layer spacing of $0.338 \mathrm{~nm}$, indicates highly ordered crystal structure. However, after undergoing oxidation, it is obviously that the characteristic of graphitic peak completely disappears and in the meantime a new diffraction peak of (002) appearing at about $2 \theta=11.04^{\circ}$ with layer spacing $0.801 \mathrm{~nm}$ which indicating the layer distance was higher than the graphite. This happens due to the oxygen functional groups attached to both side of graphene sheets and the increasing atomic scale roughness to the graphene sheets. Therefore, it can be concluded that the expandable graphite was successfully oxidized. In the meanwhile for SPEEK, it was found that it gives a broad signal around the reflections which indicated it exists as fully amorphous structure. Generally, PEEK commonly considered as semi-crystallinity polymer, and that was confirmed by the appearance of a sharp crystalline peak of the range of $20-30^{\circ}[15,16]$. However, the crystallinity has been effectively decreased after the process of sulfonation. The XRD pattern of pristine SPEEK shows a broad peak overlay with the range of $13-25^{\circ}$, which indicates the lower crystallinity of SPEEK. The incorporated GO sheets are completely covered by the SPEEK polymers; therefore, there are no significant peaks observed for the fillers in the GO-SPEEK composites which indicate crystalline GO nanosized breaks and diffuse inside SPEEK polymer chains thus produce particulate nanocomposites membranes.

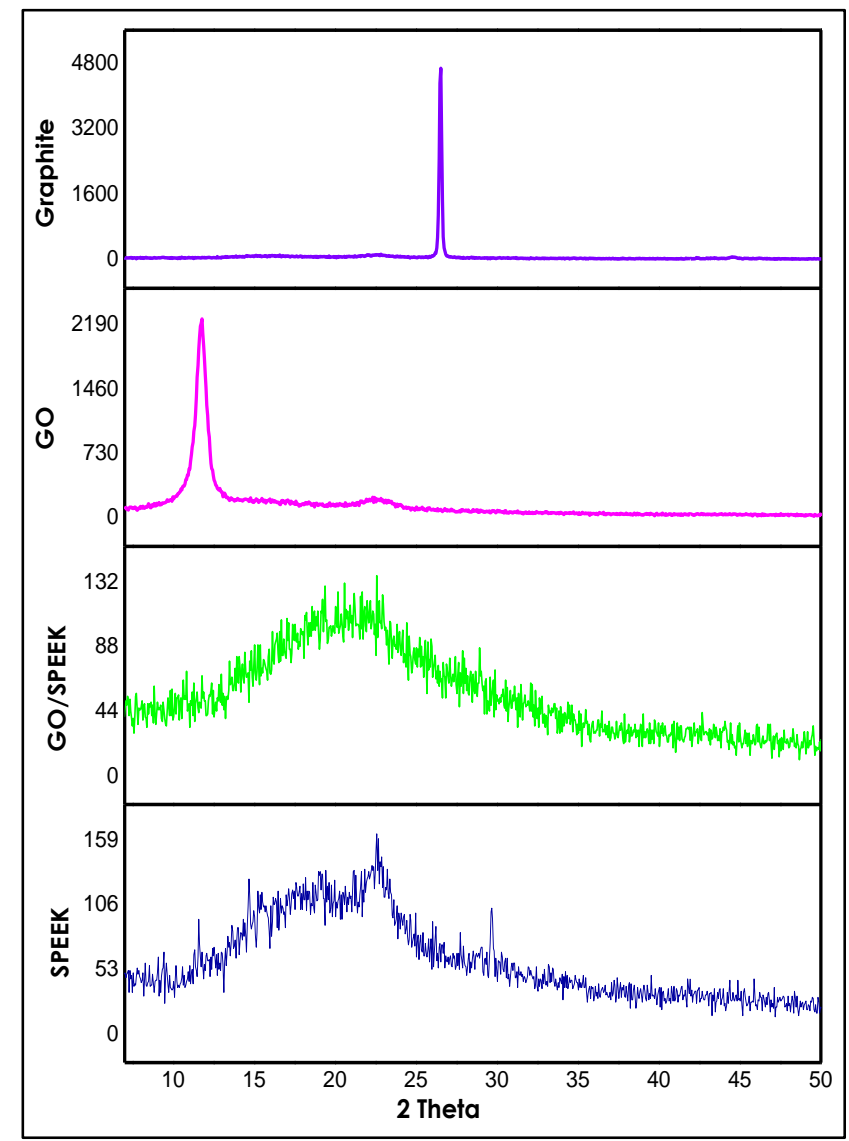

Figure 4. X-ray spectra for graphite, GO, SPEEK and GO-SPEEK 


\section{Water uptake and swelling behaviour}

Water plays a crucial role in proton exchange membranes and influence proton transport across their membranes as proton could transport along with hydrogen-bonded ionic pathway and cationic mixtures such as $\mathrm{H}_{3} \mathrm{O}^{+}, \mathrm{H}_{5} \mathrm{O}_{2}{ }^{+}$and $\mathrm{H}_{9} \mathrm{O}_{4}{ }^{+}$in the water [17]. In order for membranes to have high proton conductivity and low resistance, it is desired for them to have a high water uptake capacity. Low amount of water uptake would reduce proton transport, while too much water uptake leads to excessive swelling hence loss of the dimensional stability. Figure 5 shows the percentage of water uptake for Nafion ${ }^{\circledR} 112$, SPEEK and GO-SPEEK at varying temperature. The similar trend shows for the all samples which are the water uptake increase with the increasing temperature. Higher of temperature would introduce more movement of polymer chains as a result lead to more free volume for water absorption [9]. Plain SPEEK gives a higher water uptake percentage rather than commercial membrane, Nafion. However the plain SPEEK exhibits higher swelling percentage compared to commercial Nafion as depicted in Figure 6. This shortcoming improved when GO is introduced into the SPEEK. In line to the plain SPEEK, the composite membranes shows an increase in water uptake, even substantially enhanced two times higher than commercial membrane. This may result from the formation of hydrophilic channel within -OH on the GO edge and $-\mathrm{SO}_{3} \mathrm{H}$ groups in SPEEK which could lead decreasing of an average inter-chain distance of SPEEK. In contrast to plain SPEEK, GO-SPEEK gives a higher water uptake however surprisingly it gives lower swelling percentage compared to commercial PEM.

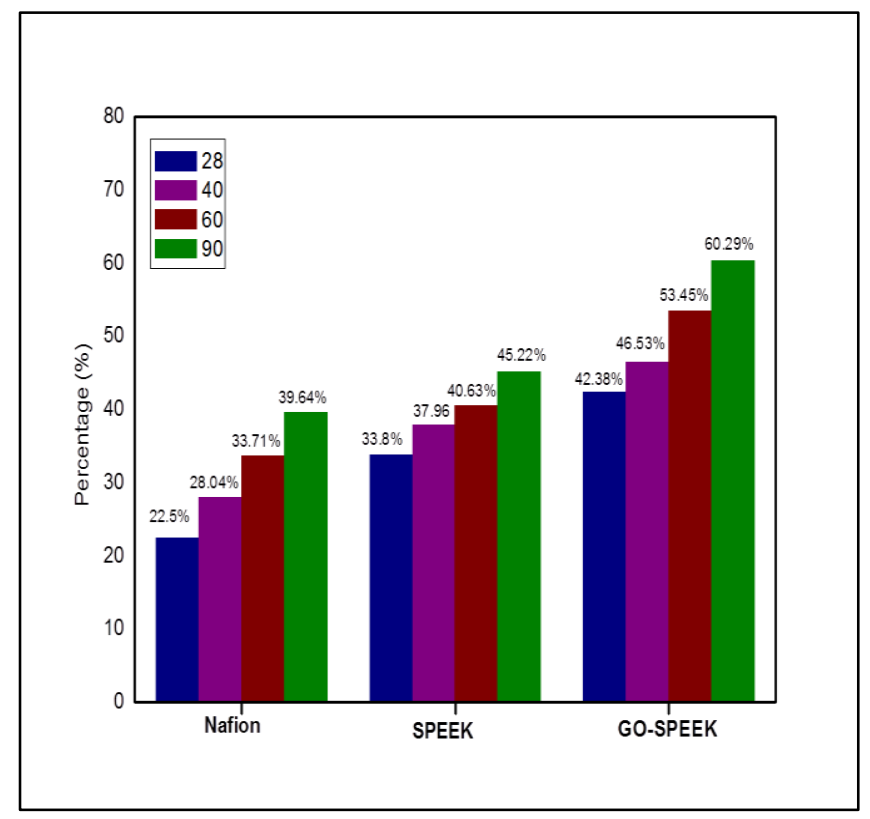

Figure 5. Percentage of water uptake for Nafion, SPEEK and GO-SPEEK at varying temperature

Table 1 depicts the value obtained for IEC and proton conductivity for Nafion, plain SPEEK and GO-SPEEK. Ionexchange capacity (IEC) is an important property for membranes intended to be used as PEMs. Membranes with high IECs is expected to transport protons effectively through the available conducting ionic sites by proton hopping mechanism[18]. Sulfonic acid based PEMs, with high acidity and high ionization power, are one of the best choices in this area. It is observed that GO-SPEEK was the most acidic membrane as it exhibited the highest IEC compared to other membrane. This is in agreement with water uptake results. 


\section{Nuor Sariyan et al: METHANOL PERMEABILITY AND PROPERTIES OF POLYMER ELECTROLYTE MEMBRANE BASED ON GRAPHENE OXIDE- SULFONATED (POLYETHER ETHER) KETONE}

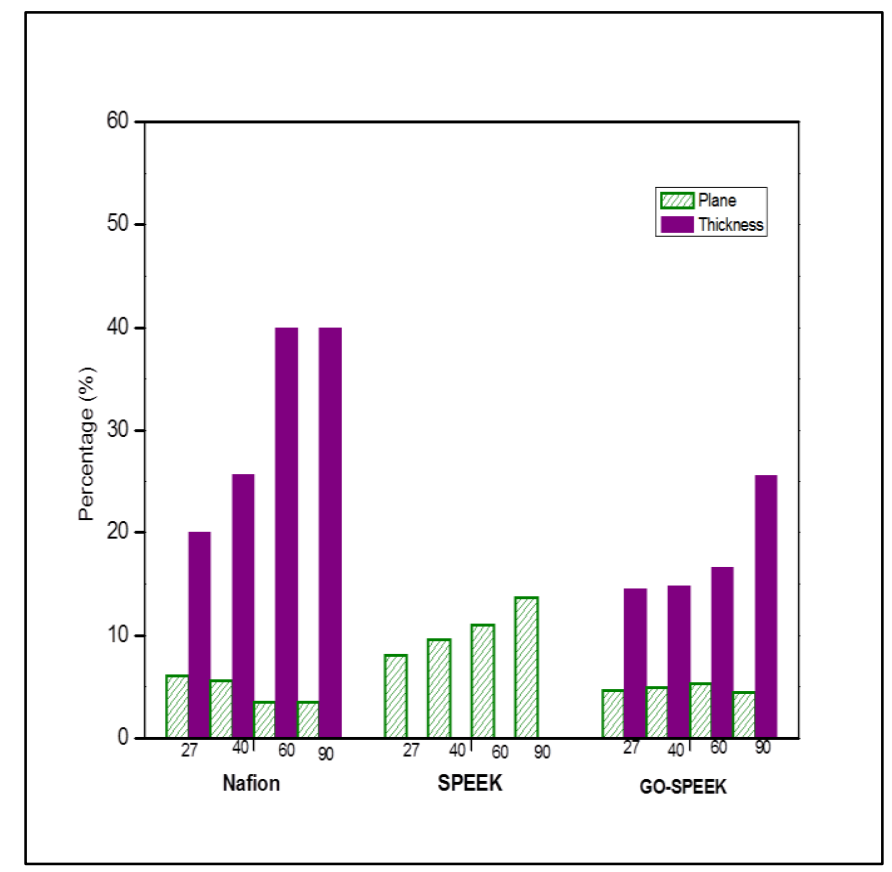

Figure 6. Percentage of swelling for Nafion, SPEEK and GO-SPEEK at varying temperature

Table 1. IEC, methanol permeability and proton conductivity $(\sigma)$ of the Nafion, plain SPEEK and GO-SPEEK membranes at $85{ }^{\circ} \mathrm{C}$

\begin{tabular}{|c|c|c|c|}
\hline Sample & $\begin{array}{c}\text { IEC } \\
(\text { mequiv.g } \\
\text { (1) }\end{array}$ & $\begin{array}{l}\text { Methanol Permeability } \\
\qquad\left(\mathbf{x ~ 1 0}^{6} \mathrm{~cm}^{2} \mathrm{~s}^{-1}\right)\end{array}$ & $\begin{array}{l}\text { Proton Conductivity } \\
\left(\mathbf{S c m}^{-1}\right)\end{array}$ \\
\hline Nafion $^{\circledR} 112$ & 0.895 & 1.59 & 0.0612 \\
\hline SPEEK & 0.982 & 0.97 & 0.0382 \\
\hline GO-SPEEK & 1.231 & 0.36 & 0.0537 \\
\hline
\end{tabular}

Proton conductivity is a crucial parameter to determine the fuel cell performance 1. As shown in Table 1, the proton conductivity of GO-SPEEK membrane a bit lowered rather than the commercial Nafion ${ }^{\circledR} 112$, however it still higher than $1 \times 10^{-2} \mathrm{Scm}^{-1}$ which regarded as the lowest value of practical interest for PEM in fuel cells $[19,20]$ Proton conductivity relies on various factors, such as water uptake, IEC and the microstructure of the membrane [21]. Based on the structure, it could be understandable that by incorporating GO, it introduces inter-connected proton transfers channel [22], which able to facilitate proton transfer through the membrane. Hence this composite membrane exhibits higher proton conductivity compared to blank SPEEK. In addition, the proton transport in membranes requires well-connected channels formed by ion clusters of hydrophilic sulfonic acid groups. Hence, the content and the diameter of the connected channels gives remarkable effect on the proton transport rate in the membrane. The formation of isolated ionic cluster in the continuous hydrophobic phase occurred when the density of sulfonic acid groups low. The ionic clusters might be blocked from the GO with low proton conductivity although the water uptake and IEC increased in GO-SPEEK.

Membranes for practical usage of PEMs in DMFC were required to possess high conductivity and low methanol permeability. The methanol permeability of GO-SPEEK, blank SPEEK, and Nafion ${ }^{\circledR} 112$ are shown in Table 1. It can be seen that the methanol permeability of SPEEK and GO-SPEEK are much lower than commercial membrane. 
These results could be explained by their microstructure. Nafion ${ }^{\circledR} 112$ membrane creates a simple hydrophobicityhydrophilicity separation because of high hydrophobicity of the perfluorinated backbone and high hydrophilicity of the attached sulfonic acid groups. These well-connected hydrophilic domains act as substance movement channels, which not restricted to only proton and water, but also smaller polar molecules such as methanol could get through these channels. This circumstance results to high value of methanol permeability. In contrast, the SPEEK has smaller hydrophobicity and hydrophilicity differences compared to commercial membrane. Thus less constructed separation into hydrophobic and hydrophilic domains yields to lower methanol permeability than Nafion [23 - 25]. When the GO incorporated into SPEEK, it functions as barrier to connect the hydrophilic channels. GO block the polar molecules, methanol from easily passing through the membrane. This phenomenon is called "blocking effect". Besides, the interfacial interaction between GO and SPEEK polymer also contributes to the decreasing of it as GO and SPEEK interaction restricts the formation of broad hydrophilic channel requires by methanol transportation [26].

\section{Conclusion}

Composite membrane based on GO-SPEEK had been successfully prepared. Physical and chemical properties were investigated. The performances of the composite membranes such as water uptake, dimensional stability, IEC, methanol permeability and proton conductivity were investigated. Though the capacity of water uptake were greatly improved with the introduction of GO into SPEEK, but it still able to reduce swelling ratio. The proton conductivities of GO-SPEEK slightly decrease compared to commercial membrane, Nafion ${ }^{\circledR} 112$. These results indicate that GO-SPEEK membranes possessed as promising PEM in fuel cell.

\section{Acknowledgement}

The author wish to acknowledge funding from the Ministry of Higher Education (MOHE) for Fundamental Research Grant Scheme (FRGS) (vote no: R.J130000.7826.4F798), the Physic Laboratory of the Faculty of Science and Material Laboratory of The Faculty of Mechanical Engineering, Universiti Teknologi Malaysia for assistance given.

\section{References}

1. Sharaf, O. Z. and Orhan, M. F. (2014). An overview of fuel cell technology: Fundamentals and applications. Renewable and Sustainable Energy Reviews, 32 (1): 810 - 853.

2. Lucia, U. (2014). Overview on fuel cells. Renewable and Sustainable Energy Reviews, 30(1): $164-169$.

3. Norddin, M. N. A. M., Ismail, A. F., Rana, D., Matsuura, T., Mustafa, A. and Tabe-Mohammadi, A. (2008). Characterization and performance of proton exchange membranes for direct methanol fuel cell: Blending of sulfonated poly(ether ether ketone) with charged surface modifying macromolecule. Journal of Membrane Science, 323(2): $404-413$.

4. Tripathi, B. P. and Shahi, V. K. (2011). Organic-inorganic nanocomposite polymer electrolyte membranes for fuel cell applications. Progress in Polymer Science (Oxford), 36(7): 945 - 979.

5. Jaafar, J., Ismail, A. F. and Matsuura, T. (2009). Preparation and barrier properties of SPEEK/Cloisite 15A®/TAP nanocomposite membrane for DMFC application. Journal of Membrane Science, 345 (1-2): 119 127.

6. Chakraborty, S., Guo, W. H., Hauge, R. H. and Billups, W. E. (2008). Reductive alkylation of muorinated graphite. Chemistry of Materials, 20(9): $3134-3136$.

7. Hummers, W. S. and Offeman, R. E. (1958). Preparation of graphitic oxide. Journal of the American Chemical Society, 80 (6):1339 - 1339.

8. Jaafar, J., Ismail, A. F. and Matsuura, T. (2012). Effect of dispersion state of Cloisite15A on the performance of SPEEK/Cloisite15A nanocomposite membrane for DMFC application. Journal of Applied Polymer Science, 124 (2): $969-977$.

9. Park, C. H., Lee, C. H., Guiver, M. D. and Lee, Y. M. (2011). Sulfonated hydrocarbon membranes for mediumtemperature and low-humidity proton exchange membrane fuel cells (PEMFCs). Progress in Polymer Science (Oxford), 36 (11): 1443 - 1498.

10. Kudin, K. N., Ozbas, B., Schniepp, H. C., Prud'homme, R. K., Aksay, I. A. and Car, R. (2008). Raman spectra of graphite oxide and functionalized graphene sheets. Nano Letters, 8(1): $36-41$. 
11. Ferrari, A. C., Meyer, J. C., Scardaci, V., Casiraghi, C., Lazzeri, M. and Mauri F. (2006). Raman spectrum of graphene and graphene layers. Physical Review Letters, 97 (18): $74-81$.

12. Childres, I., Jauregui, L., Park, W., Cao, H. and Chen, Y. (2013). Raman spectroscopy of graphene and related materials. New Developments in Photon and Materials Research, 16 (2): 1 - 20.

13. Tuinstra, F. and Koenig, L. (1970). Raman spectrum of graphite. The Journal of Chemical Physics, 53 (1): $1126-1130$.

14. Ferrari, A.C. and Basko, D. M. (2013). Raman spectroscopy as a versatile tool for studying the properties of graphene. Nature Nanotechnology, 8(4): 235 - 246.

15. Mecheri, B., D'Epifanio, A., Traversa, E. and Licoccia S. (2008). Sulfonated polyether ether ketone and hydrated tin oxide proton conducting composites for direct methanol fuel cell applications. Journal of Power Sources, 178(2): $554-560$.

16. Krishnan, P., Park, J. S. and Kim, C. S. (2006). Preparation of proton-conducting sulfonated poly(ether ether ketone)/boron phosphate composite membranes by an in situ sol-gel process. Journal of Membrane Science, 279 (6): $220-229$.

17. Fu, T., Cui, Z., Zhong, S., Shi, Y., Zhao, C. and Zhang, G. (2008). Sulfonated poly(ether ether ketone)/clay$\mathrm{SO}_{3} \mathrm{H}$ hybrid proton exchange membranes for direct methanol fuel cells. Journal of Power Sources, 185(5): 32 -39 .

18. Hasani-sadrabadi, M. M., Emami, S. H. and Ghaffarian, R. (2008). Nanocomposite membranes made from sulfonated poly (ether ether ketone) and montmorillonite clay for fuel cell applications. Energy \& Fuels, 22(4): $2539-2542$.

19. Peighambardoust, S. J., Rowshanzamir, S. and Amjadi, M. (2010). Review of the proton exchange membranes for fuel cell applications. International Journal of Hydrogen Energy, 35(17): 9349 - 9384.

20. Barbir, F. (2006). PEM fuel cells. Fuel Cell Technology, 2(1): $27-51$.

21. Eisenberg A. (1970). Clustering of ions in organic polymers. A theoretical approach. Mucromolecules, 3(2): $147-154$.

22. He, Y., Tong, C., Geng, L. and Liu, L. (2014). Enhanced performance of the sulfonated polyimide proton exchange membranes by graphene oxide: Size effect of graphene oxide. Journal of Membrane Science, 458(2): $36-46$.

23. Jiang, Z., Zhao, X. and Manthiram, A. (2013). Sulfonated poly(ether ether ketone) membranes with sulfonated graphene oxide fillers for direct methanol fuel cells. International Journal of Hydrogen Energy, 38 (14): 5875 5884.

24. Li, L., Zhang, J. and Wang Y. (2003). Sulfonated poly(ether ether ketone) membranes for direct methanol fuel cell. Journal of Membrane Science, 226(3): 159 - 167.

25. Li, X., Liu, C., Lu, H., Zhao, C., Wang, Z. and Xing, W. (2005). Preparation and characterization of sulfonated poly(ether ether ketone ketone) proton exchange membranes for fuel cell application. Journal of Membrane Science, 255(1-2): $149-155$.

26. Heo, Y., Im, H. and Kim, J. (2013). The effect of sulfonated graphene oxide on sulfonated poly (ether ether ketone) membrane for direct methanol fuel cells. Journal of Membrane Science, 425(1): 11 - 22. 